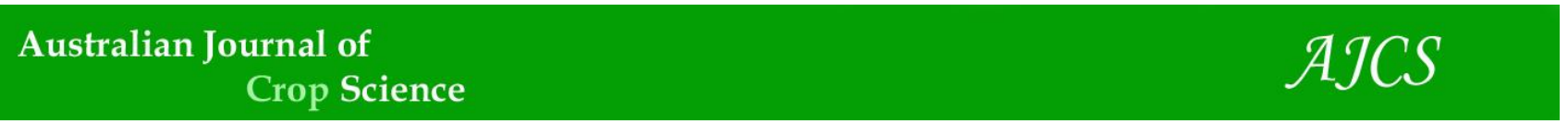

AJCS 15(02):196-200 (2021)

ISSN:1835-2707

doi: 10.21475/ajcs.21.15.02.p2549

\title{
Effect of salicylic acid in post-harvest quality of 'BRS Kampai' peaches submitted to different cold storage periods
}

\author{
Jorge Atílio Benati ${ }^{1 *}$, Caroline Farias Barreto', Renan Navroski', Roseli de Mello Farias ${ }^{2}$, Carlos Roberto \\ Martins $^{3}$, Marcelo Barbosa Malgarim ${ }^{4}$
}

\author{
'School of Agronomy Eliseu Maciel, Federal University of Pelotas, Capão do Leão Campus, Pelotas, RS, Brazil \\ ${ }^{2}$ State University of Rio Grande do Sul, São Borja, RS, Brazil \\ ${ }^{3}$ Embrapa Clima Temperado, Pelotas, RS, Brazil \\ ${ }^{4}$ School of Agronomy Eliseu Maciel, Federal University of Pelotas, Capão do Leão Campus, Pelotas, RS, Brazil
}

*Corresponding author: jorgeatiliobenati@hotmail.com

\begin{abstract}
Fast ripening of fruits is one of the main hindrances to peach preservation. Even though the use of cold storage has extended commercialization periods, fruit quality is affected during storage. This study aimed at evaluating the influence of application of salicylic acid (SA) during cold storage, followed by commercialization simulation, regarding physical and chemical characteristics of 'BRS Kampai' peaches, which were harvested in the 2017 crop. The experiment was conducted in a completely randomized factorial design $(4 \times 3$ : SA concentrations $\times$ storage days), with four replications of ten fruits each. SA was applied at the following concentrations: $0,2,4$ and $6 \mathrm{mM}$. Afterwards, fruits were submitted to cold storage at $1 \pm 0.5$ o $\mathrm{C}$ and $80-85 \%$ relative humidity. Analyses were carried out on harvest day, on the 10th cold storage day, followed by a day at room temperature $\left(20^{\circ} \mathrm{C}\right)$ and on the 20th cold storage day, followed by a day at room temperature. Fruits were evaluated in terms of their mass loss, epidermis color, chromatic hue, pulp firmness, soluble solids (SS), pH and titratable acidity (TA). Both application of SA and cold storage contributed to decrease mass loss and TA, besides increasing the SS/TA relation. Fruits which were stored for 20 days and kept at room temperature for a day exhibited the highest values of SS and the lowest values of both brightness and pulp firmness. SA was efficient to maintain the quality of 'BRS Kampai' peaches submitted to cold storage for 10 and 20 days and an extra day of commercialization simulation.
\end{abstract}

Keywords: Prunus persica (L.), preservation, fruit farming

Abbreviations: SA_Salicylic Acid; SS_Soluble Solids; TA_Titratable acidity; L*_Brightness; a*_Red/green coordinate; b*_yellow/ blue coordinate; Ratio_Result of the SS/TA relation

\section{Introduction}

Peaches have been characterized as extremely perishable fruits which may have their quality highly affected if there is no adequate post-harvest management (Cantillano, 2014). They are climacteric fruits of high perishability that undergo senescence acceleration after harvest, when water loss increases and quality decreases during storage. As a result, peaches need to be consumed or commercialized immediately after harvest; if the offer period must be extended, some method of cold storage should be used (Pinto et al., 2012; Pegoraro et al., 2016). Among commercial methods of fruit preservation, refrigeration with temperature and relative humidity controls are the most common one (Pegoraro et al., 2010; Pinto et al., 2012).

In peach commercialization, production of high-quality fruit is fundamental. Cold storage aims at maintaining maximum fruit quality. Trevisan et al. (2010) report that certain attributes, such as size, color, taste and absence of defects, attract consumers and are decisive factors when they buy fruits. In the fresh fruit market, some great consumer centers, such as the southeastern region in Brazil, prefer sweet white-fleshed peaches (Almeida and Durigan 2006).
Thus, the cultivar 'BRS Kampai', whose origin is the crossing between cultivars 'Chimarrita' and 'Flordaprince', was developed by the Embrapa Clima Temperado, in Pelotas, Rio Grande do Sul (RS) state, Brazil, to bear sweet, whitefleshed, semi-cling stone, slightly acid peaches which are recommended for fresh consumption (Raseira et al., 2014). In order to extend commercialization time of peaches, mainly the ones borne by cultivars that aim at the fresh fruit market, salicylic acid (SA) has been used for regulating plant growth (Taiz et al., 2017). SA has a broad role as a signaling molecule in plants, since it activates several forms of resistance (Asghari and Aghdam, 2010). When it is applied exogenously, this molecule has been considered an alternative to mitigate senescence in some plant species. Many studies of post-harvest periods of fruit, such as peaches (Barreto et al., 2016), blaclberries (Borsatti et al., 2015), strawberries (Ghaderi, et al., 2015; Salari et al, 2012), oranges (Rossarolla et al., 2012) and apples (Quaglia et al., 2011) used SA and showed that this compound is capable of decreasing post-harvest loss. SA has been related to senescence retardation, since it has an antagonistic effect on 
ethylene biosynthesis and may decrease its production in up to $30 \%$ (Imran et al., 2007; Khademi et al., 2012). Application of SA increases fruit resistance to injuries caused by the cold (Luo et al., 2011), keeps pulp firmness (Asghari and Aghdam, 2010) and inhibits enzymes that are responsible for cell wall and membrane degradation (Zhang et al., 2003). It should be highlighted that AS is considered safe for consumers (Supapvanich and Promyou, 2013) because it is a natural component of fruit (Belitz and Grosch, 2004). Studies of preservation techniques, along with cold storage, are important not only to extend peach preservation and postharvest quality but also to enable the best conditions of commercialization to be employed (Mazaro et al., 2015). Therefore, this study aimed at evaluating the quality of 'BRS Kampai' peaches submitted to different SA concentrations in post-harvest and to distinct cold storage periods followed by a day of commercialization simulation.

\section{Results and discussion}

\section{Mass loss}

SA application decreased peach mass loss in both storage periods (Figure 1). In the storage period $10+1$, the lowest mass loss was exhibited by the concentration of 2 mM SA. However, in the storage period $20+1$, the highest SA concentrations, i. e., 4 and $6 \mathrm{mM}$, were the ones that led to the best results. Decrease in fruit fresh mass results from the natural senescence process throughout the storage period. According to Alves et al. (2010), fruit mass loss, which is mainly caused by decrease in water through transpiration and respiration processes, leads to decrease in product quality. SA may influence permeability of the plasma membrane of the pericarp indirectly and, thus, lead to low water loss in the form of vapor to the environment (Rossarolla et al., 2012). Similar results were found in strawberries to which SA was applied at different developmental stages (Lolaei et al., 2012) and in peaches stored at cold temperatures (Khademi et al., 2012).

\section{Firmness of peach pulp}

Regardless peach pulp firmness, both concentrations of 2 $\mathrm{mM}$ and $6 \mathrm{mM}$ SA were the ones that exhibited the best results on the $10+1$ day, while $6 \mathrm{mM}$ was the concentration that kept it longer (Table 1). Even though application of SA does not follow a certain trend, maintenance of pulp firmness was observed. It may have happened because SA is related to ethylene inhibition in the ripening process; thus, it inhibits degradation of enzymes that decrease fruit softening (Zhang et al., 2003; Asghari and Aghdam, 2010). Concerning storage periods, pulp firmness decreased after cold storage (Table 1). Decrease in peach pulp firmness occurred due to solubilization of cell wall components (Pegoraro et al., 2016). These results agree with the ones found by Barreto et al. (2017).

\section{Titratable acidity and ratio}

Regarding TA, treatments whose concentrations were 2 and $6 \mathrm{mM} \mathrm{SA}$ had the highest acidity values on the 10+1 day (Table 2). However, on the 20+1 day, $6 \mathrm{mM}$ SA was the concentration that led to the lowest acidity, it is evidence of higher ripening when fruits are stored for a longer period.
Since TA is composed of concentrations of organic acids in cells, their contents tend to decrease in the ripening process, because they are either used as a substrate in the respiratory process or converted into sugar. This decrease may also be related to the use of citric acid as respiratory substrate (Barreto et al., 2016).

Concerning the SS/TA relation, the treatment that exhibited the best result on the $10+1$ day was the dose of $4 \mathrm{mM} \mathrm{SA}$, even though it did not differ from the control treatment. When fruits were stored for 20+1 days, the dose of $6 \mathrm{mM} \mathrm{SA}$ resulted in the highest value. In general, peaches whose SS/TA values were equal or above 20 taste good (Cantillano et al., 2014). Thus, all treatments kept contents of SS and SS/TA in a normal range in the case of fruits borne by peach trees.

Parameters of luminosity, soluble solids, color, $\mathrm{pH}$ and Chroma

There was no interaction between storage periods and SA concentrations in the case of the following variables: SS, luminosity $\left(\mathrm{L}^{*}\right),{ }^{\circ} \mathrm{Hue}, \mathrm{pH}$ and Chroma. Thus, effects of storage time and SA concentrations are introduced and discussed separately (Table 3).

SS of peaches exhibited their highest values in the control treatment, whereas the treatment with $2 \mathrm{mM}$ SA led to the lowest value of SS (Table 3). In general, SA concentrations decrease SS in fruits because they retard ripening. Khademi et al., (2012) applied doses of 1 and 2 mM SA to peaches in post-harvest and decreased their SS in cold storage.

Values of SS increased throughout cold storage periods (Table 3). Increase in SS during storage may be due to the loss of mass that concentrates fruit juice (Moreno et al, 2008).

Regarding epidermis luminosity $\left(L^{*}\right)$, no alteration was observed after treatments with SA application (Table 3 ). However, this variable exhibited change related to storage periods, i. e., fruits decreased values of luminosity as storage days went by. According to Brecht et al. (2007), epidermis darkening occurs as the result of oxidation reactions of phenolic compounds found in plant tissue.

Values of pulp $\mathrm{pH}$ were influenced neither by treatments with SA nor by cold storage. $\mathrm{pH}$ represents direct concentration of $\mathrm{H}^{+}$ions in solutions. According to Alcobendas et al. (2013), this attribute in peaches depends more on their orientation in plants and on sunlight exposure; besides, it usually decreases as diameters of fruits increase.

'Hue expresses differences in the color of fruit epidermis (saturation) and enables changes in colors, from green to yellow, to be observed (Azzolini et al., 2004). The CIELAB system states that high ${ }^{\circ}$ Hue values in peaches show greenish epidermis and that, the lower the value, the redder the fruit. Table 3 shows that neither SA application nor storage periods exhibited significant difference. i. e., they did not influence peach color. These results corroborate the ones found by Tareen et al. (2012) and Silva et al. (2016), who reported that epidermis color of peaches was not influenced by SA concentrations.

Chroma is the variable that defines color intensity, but SA concentrations exhibited no differences (Table 3). Considering storage periods, on the $20+1$ day, chromatic 
Table 1: Pulp firmness $(\mathrm{N})$ in fruits borne by 'BRS Kampai' peach trees submitted to different SA concentrations and to distinct cold storage periods.

\begin{tabular}{lllllll}
\hline Pulp firmness (N) & & & & & & \\
\hline Control & 26.73 & aA & 14.19 & $b B$ & 8.91 & $b C$ \\
2 mM de SA & 26.73 & aA & 19.39 & aB & 11.72 & aC \\
4 mM de SA & 26.73 & aA & 14.33 & bB & 11.17 & baC \\
6 mM de SA & 26.73 & aA & 18.44 & aB & 9.85 & $\mathrm{baC}$ \\
CV (\%) & - & & 7.96 & & 7.96 & \\
\hline
\end{tabular}

Means followed by the same capital letter on a line and small letter in a column do not differ by the Tukey's test at $5 \%$ error probability. CV (\%): coefficient of variation.

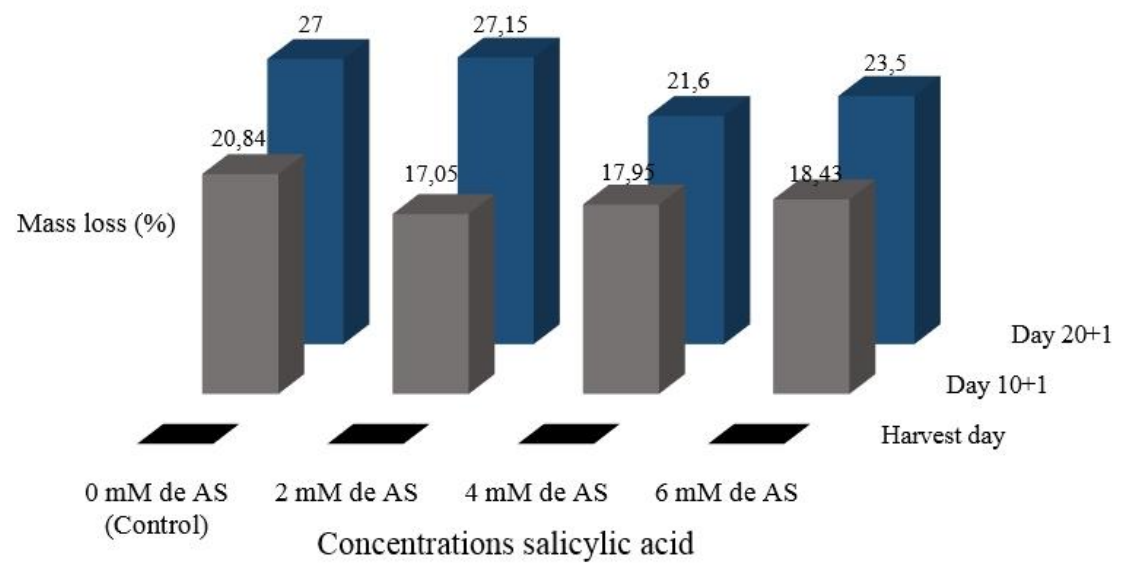

Fig 1. Graph of percentages of mass loss, salicylic acid doses $(0,2,4$ and $6 \mathrm{mM}$ ) applied postharvest, storage periods (harvest day, 10 and 20 days at $\left.1 \pm 0.5^{\circ} \mathrm{C}\right)$ and 1-day shelf life simulation $\left(20 \pm 1^{\circ} \mathrm{C}\right)$. UFPel, Pelotas, RS, Brazil.

Table 2. Titratable acidity (TA) and soluble solids/titratable acidity ratio (SS/TA) in pulp of fruits borne by 'BRS Kampai' peach trees submitted to different SA concentrations and to distinct cold storage periods.

\begin{tabular}{|c|c|c|c|c|c|c|}
\hline \multicolumn{7}{|c|}{ Titratable acidity (TA) (g of citric acid/100mL juice) } \\
\hline & \multicolumn{3}{|c|}{ Harvest day } & \multirow{2}{*}{$\frac{\text { Day } 10+1}{a b B}$} & \multicolumn{2}{|c|}{ Day $20+1$} \\
\hline Control & 0.35 & $\mathrm{aA}$ & 0.47 & & 0.53 & $\mathrm{aC}$ \\
\hline $2 \mathrm{mM}$ de $\mathrm{SA}$ & 0.35 & $\mathrm{aA}$ & 0.51 & $a B$ & 0.51 & $a B$ \\
\hline $4 \mathrm{mM}$ de $\mathrm{SA}$ & 0.35 & $\mathrm{aA}$ & 0.43 & bB & 0.50 & $\mathrm{aC}$ \\
\hline $6 \mathrm{mM}$ de SA & 0.35 & $\mathrm{aA}$ & 0.50 & $\mathrm{aC}$ & 0.45 & $b B$ \\
\hline CV (\%) & - & & 5.94 & & 5.94 & \\
\hline \multicolumn{7}{|l|}{ SS/TA } \\
\hline Control & 32.87 & $\mathrm{aA}$ & 31.00 & $a b A$ & 28.34 & $a b A$ \\
\hline $2 \mathrm{mM}$ de $\mathrm{SA}$ & 32.87 & $\mathrm{aA}$ & 24.50 & $c B$ & 27.95 & $a b A B$ \\
\hline $4 \mathrm{mM}$ de $\mathrm{SA}$ & 32.87 & $\mathrm{aA}$ & 32.01 & $\mathrm{aA}$ & 27.85 & $\mathrm{bA}$ \\
\hline $6 \mathrm{mM}$ de $\mathrm{SA}$ & 32.87 & $\mathrm{aA}$ & 26.23 & $b c B$ & 33.47 & $\mathrm{aA}$ \\
\hline CV (\%) & - & & 9.61 & & 9.61 & \\
\hline
\end{tabular}

Means followed by the same capital letter on a line and small letter in a column do not differ by the Tukey's test at $5 \%$ error probability. CV (\%): coefficient of variation.

Table 3. Contents of soluble solids (SS), epidermis luminosity $\left(\mathrm{L}^{*}\right), \mathrm{pH}$, epidermis color ( $\left.{ }^{\circ} \mathrm{Hue}\right)$ and chroma in pulp of fruits borne by 'BRS Kampai' peach trees submitted to different SA concentrations and to distinct cold storage periods.

\begin{tabular}{llllll}
\hline Treatments & SS & $\mathbf{L}^{*}$ & $\mathbf{p H}$ & ('Hue) $^{\circ}$ & Chroma \\
\hline Control & $13.68 \mathrm{a}$ & $64.75^{\mathrm{ns}}$ & $4.51^{\text {ns }}$ & $75.58^{\text {ns }}$ & $30.82^{\text {ns }}$ \\
2 mM de SA & $12.76 \mathrm{~b}$ & 64.70 & 3.99 & 77.66 & 30.78 \\
$4 \mathrm{mM}$ de SA & $13.06 \mathrm{ab}$ & 65.15 & 4.05 & 75.03 & 30.63 \\
6 mM de SA & $13.19 \mathrm{ab}$ & 65.65 & 4.00 & 77.28 & 30.82 \\
\hline Periods & & & & & \\
\hline Harvest day & $11.5 \mathrm{c}$ & $68.54 \mathrm{a}$ & $4.06^{\mathrm{ns}}$ & $77.76^{\text {ns }}$ & $28.71 \mathrm{a}$ \\
Day 10+1 & $13.5 \mathrm{~b}$ & $63.34 \mathrm{~b}$ & 4.34 & 74.28 & $31.18 \mathrm{~b}$ \\
Day 20+1 & $14.6 \mathrm{a}$ & $63.30 \mathrm{~b}$ & 4.02 & 77.13 & $32.40 \mathrm{c}$ \\
CV (\%) & 6.04 & 3.49 & 20.75 & 6.95 & 3.73 \\
\hline
\end{tabular}

Means followed by different letters in columns differ by the Tukey's test at 5\% error probability. CV (\%): coefficient of variation. ns: non-significant at $5 \%$ error probability. 
intensity was higher, a fact that shows the highest level of fruit ripening.

\section{Materials and methods}

\section{Area of experiment and plant material}

The experiment was carried out in the Laboratory of Fruit Quality that belongs to the Universidade Federal de Pelotas, located in Capão do Leão, RS, Brazil, with peaches borne by the cultivar 'BRS Kampai'. Fruits that had lesions and little weight were discarded so as to homogenize samples.

\section{Treatments and experimental design}

The experiment was conducted in a completely randomized factorial design (4 SA concentrations $\times 3$ storage periods), with four replications of ten fruits each. The following SA concentrations were applied to the peaches: T1: $0 \mathrm{mM}$ (Control treatment); T2: $2 \mathrm{mM}$; T3: $4 \mathrm{mM}$; and T4: $6 \mathrm{mM}$, which were previously solubilized in $20 \mathrm{~mL}$ ethylic alcohol. Fruits were sprinkled on both sides by a manual pressure sprayer. On average, $2 \mathrm{~mL}$ solution with SA was applied to every fruit. After application of SA, peaches were stored in a cold chamber at $1 \pm 0.5 \circ \mathrm{C}$ and $80-85 \%$ relative humidity. Analyses were carried out in the following periods: on harvest day; on the 10th cold storage day, followed by a day at room temperature $\left(20^{\circ} \mathrm{C}\right)$, to simulate commercialization time (10+1); and on the 20th cold storage day, followed by a day at room temperature $(20+1)$.

\section{Traits under evaluation}

The following variables were analyzed: fresh mass loss, which was determined by the difference between fruit mass at harvest time and in the period of fruit quality evaluation, expressed as percentage (\%); surface color, which was measured on the medium part of the sample by a Minolta CR- $300^{\circ}$ colorimeter, with a D65 light source, readings of coordinates $\mathrm{L}^{*}, \mathrm{a}^{*}$ and $\mathrm{b}^{*}$ and shade or chromatic hue represented by the hue angle $(\mathrm{H} N)$; chroma, which was the relation between values of "a" and "b"; pulp firmness, which was measured by a manual TR TURONI-Italy penetrometer, model 53205, with an 8-mm tip, in two opposite spots in the equatorial area of fruits, expressed as Newtons (N); soluble solids (SS), which were determined by an Atago $^{\circ}$ digital refractometer, expressed as -Brix in juice; titratable acidity (TA), which was determined by diluting $10 \mathrm{~mL}$ juice in $90 \mathrm{~mL}$ distilled water that was titrated up to $\mathrm{pH} 8.1$ with $\mathrm{NaOH} 0.1$ $\mathrm{mol} / \mathrm{L}$ (results were expressed as percentage of citric acid); and hydrogenionic potential $(\mathrm{pH})$, which was measured by a Quimus ${ }^{\circledast}$ Hmeter.

\section{Statistical analysis}

Resulting data were submitted to the analysis of variance by the F-Test and means were compared by the Tukey's test, where $p \leq 0.05$. The Sisvar software was used for conducting the statistical analysis (Ferreira, 2014).

\section{Conclusion}

SA alters pulp firmness and helps to decrease fruit mass in peaches submitted to cold storage. Luminosity, epidermis color and $\mathrm{pH}$ are not affected by SA application. Epidermis luminosity decreased throughout storage periods.

Results show that both SA application and cold storage are alternatives to keep fruit quality and, consequently, to preserve peaches for a longer period after harvest. However, further studies should be carried out to adjust these techniques to post-harvest technology for peaches.

\section{Acknowledgements}

The authors wish to thank the National Council for Scientific and Technological Development (CNPq) and the Coordination of Improvement of Higher Education Personnel (CAPES) for the support.

\section{References}

Alcobendas R, Mirás-Avalos JM, Alarcón, JJ, Nicolás E (2013) Effects of irrigation and fruit position on size, colour, firmness and sugar contents of fruits in a mid-late maturing peach cultivar. Sci Hort. 164: 340-347.

Almeida GVBD, Durigan JF (2006) Relação entre as características químicas e o valor dos pêssegos comercializados pelo sistema veiling frutas Holambra em Paranapanema-SP. Rev Bras Frutic, 218-221.

Alves EDO, Steffens CA, Talamini do Amarante CV, Weber A, Miqueloto A, Brackmann, A (2010) Armazenamento refrigerado de ameixas' Laetitia'com uso de 1-MCP e indução de perda de massa fresca. Ciênc Rural. 40(1).

Asghari M, Aghdam, MS (2010) Impact of salicylic acid on postharvest physiology of horticultural crops. Trends Food Sci Technol, 21(10): 502-509.

Azzolini M, Jacomino AP, Bron IU (2004) Índices para avaliar qualidade pós-colheita de goiabas em diferentes estádios de maturação. Pesq Agropec Bras. 39(2): 139-145.

Barreto CF, Kirinus M, Giovanaz MA, Silva PS, Navroski R, Fachinello JC, Malgarim MB (2017) Conservação de pêssegos 'Rubimel'com uso de ácido salicílico na pré e pós-colheita. Spacios, 38(36): 03.

Barreto CF, Kirinus M, Santos PS, Malgarim MB, Fachinello JC (2016) Ácido salicílico na pós-colheita para redução de podridão parda e manutenção qualidade de pêssego 'chiripá'. Ver Iberoam Tec Postcosecha. 17(1): 50-57.

Borsatti FC, Mazaro SM, Danner MA, Nava GA, Dalacosta NL (2015) Indução de resistência a qualidade pós-colheita de amora-preta tratada com ácido salicílico. Rev Bras Frutic. 37(2):318-326.

Brecht JK, Saltveit ME, Talcott ST, Moretti CL (2007) Alterações metabólicas. Manual de Processamento Mínimo de Frutas e Hortaliças. Brasília-DF: Embrapa Hortaliças.

Cantillano RFF (2014) Manejo e conservação pós-colheita: fisiologia e tecnologia cap. 20 p.559-603. In: Raseira MCB, Pereira JFM, Carvalho FLC Pessegueiro, Embrapa, 776p.

Ferreira DF (2014) Sisvar: a Guide for its Bootstrap procedures in multiple comparisons. Ciênc agrotec. 38(2): 109-112.

Ghaderi N, Normohammadi S, Javadi T (2015) Morphophysiological responses of Strawberry (Fragaria $x$ ananassa) to exogenous salicylic acid application under drought stress. J Agr Sci Tech. 17(1):167-178.

Imran H, Zhang Y, Du G, Wang G, Zhang J (2007) Effect of salicylic acid (SA) on delaying fruit senescence of Huang Kum pear. Frontiers of Agriculture in China. 1(4): 456-459.

Khademi O, Zamani Z, Mostofi Y, Kalantari S, Ahmadi A (2012) Extending storability of persimmon fruit cv. Karaj by 
postharvest application of salicylic acid. J Agric Sci Technol. 14(5): 1067-1074.

Lolaei A, Kaviani B, Rezaei MA, Raad MK, Mohammadipour R (2012) Effect of pre-and postharvest treatment of salicylic acid on ripening of fruit and overall quality of strawberry (Fragaria ananasa Duch cv. Camarosa) fruit. Ann Biol Res. 3(10): 4680-4684.

Luo Z, Chen C, Xie J (2011) Effect of salicylic acid treatment on alleviating postharvest chilling injury of 'Qingnai'plum fruit. Postharvest Biol Tec. 62(2): 115-120.

Mazaro SM, Borsatti FC, Dalacosta NL, Lewandowski A, Danner MA, Busso C, Junior AW (2015) Qualidade pós-colheita de acerolas tratadas com ácido salicílico. Rev Bras Cien Agrárias. 10(4): 512-517.

Moreno JJ, Cerpa-Calderón F, Cohen SD, Fang Y, Qian M, Kennedy JA (2008) Effect of postharvest dehydration on the composition of pinot noir grapes (Vitis vinifera L.) and wine. Food Chem. 109(4): 755-762.

Pegoraro C, Storch TT, Crizel GR, Rombaldi CV, Girardi CL (2016) Identification of biomarkers associated to 'Gala'apples ripening and postharvest quality. Comun Scien. 7(4): 494-503.

Pegoraro C, Zanuzo MR, Chaves FC, Brackmann A, Girardi CL, Lucchetta L, Rombaldi CV (2010) Physiological and molecular changes associated with prevention of woolliness in peach following pre-harvest application of gibberellic acid. Postharvest Biol Tec. 57(1): 19-26.

Pinto JAV, Brackmann A, Schorr MRW, Venturini TL, Thewes FR (2012) Induction of mass loss in post-harvest quality of 'Eragil' peaches in cold storage/Inducao de perda de massa na qualidade pos-colheita de pêssegos 'Eragil' em armazenamento refrigerado. Cienc Rural. 42(6): 962-969.
Quaglia M, Ederli L, Pasqualini S, Zazzerini A (2011) Biological control agentes and chemicas induceres of resistance for postharvest control of Penicillium expansum link. on apple fruit. Postharvest Biol Technol. 59(3):307-315.

Raseira M do CB, Pereira JFM, Carvalh FLC (2014) Pessegueiro: Embrapa Clima Temperado. 1 ed. Brasília, p.73- 142.

Rossarolla MD, Tomazetti TC, Copatti AS, de Melo Monteiro A, Righi PS, Heiffig-del Aguila LS, del Aguila JS (2012) O ácido salicílico em pré-colheita influência o controle pós-colheita de penicillium digitatum de laranja 'salustiana'. Rev Iberoam Tec Postcosecha. 13(2): 140-145.

Salari N, Baharaminejad A, Afsharmanesh G, Khajehpour G (2012) Effect of salicylic acid on post-harvest quantitative and qualitative traits of strawberry cultivars. Adv Environ Biol. 7(1):94-99.

Silva PS, Barreto CF, Moreno MB, Schiavon AV, de Mello Farias PC, Fachinello JC (2016) Pêssegos 'sensação' submetidos inoculação de monilinia fructicola e aplicação de ácido salicílico em pós-colheita. Rev Iberoam Tec Postcosecha. 17(2): 241-246.

Tareen MJ, Abbasi NA, Hafiz IA (2012) Postharvest application of salicylic acid enhanced antioxidant enzyme activity and maintained quality of peach cv. 'Flordaking' fruit during storage. Sci Horti. 142(1):, 221-228.

Taiz L, Zeiger E, Møller IM, Murphy A (2017), Fisiologia e desenvolvimento vegetal. Artmed Editora.

Trevisan R, Piana CDB, Treptow RDO, Gonçalves ED, Antunes LEC (2010) Perfil e preferências do consumidor de pêssego (Prunus persica) em diferentes regiões produtoras no Rio Grande do Sul. Rev Bras de Frutic. 32(1): 90-100.

Zhang Y, Chen K, Zhang S, Ferguson I (2003) The role of salicylic acid in postharvest ripening of kiwifruit. Postharvest Biol Tec. 28(1): 67-74. 